\title{
KEBERADAAN DAN MULTIRESISTENSI ANTIBIOTIK Salmonella spp. DARI PRODUK PERIKANAN SEGAR DI WILAYAH DKI JAKARTA DAN BOGOR
}

\section{Occurrence and Multidrug Resistance of Salmonella spp. Isolated from Fresh Seafood Products in DKI Jakarta and Bogor}

\author{
Yusma Yennie ${ }^{1 *}$, Rizky Aulia², dan Tri Handayani $\mathrm{K}^{2}$ \\ ${ }^{1}$ Balai Besar Riset Pengolahan Produk dan Bioteknologi Kelautan dan Perikanan, \\ JI. KS Tubun Petamburan VI, Slipi, Jakarta, Indonesia \\ 2 Jurusan Biologi, Fakultas MIPA, Universitas Negeri Jakarta \\ *Korespondensi Penulis: yenni.yusma@gmail.com \\ Diterima: 2 Maret 2017; Disetujui: 15 Mei 2017
}

\begin{abstract}
ABSTRAK
Salmonella spp. pada produk perikanan dilaporkan cukup tinggi prevalensinya dan erat kaitannya dengan kasus kejadian luar biasa (KLB) seperti demam, mual, muntah dan diare. Penelitian ini bertujuan untuk mengetahui prevalensi Salmonella spp. pada produk perikanan segar yang terdiri dari 110 sampel udang, 23 sampel ikan, 4 sampel cumi-cumi, dan 4 sampel kerang serta resistensinya terhadap antibiotik. Sampel diperoleh dari pasar tradisional dan modern di 5 wilayah kotamadya DKI Jakarta dan kota Bogor dengan metode purposive random sampling yang dilakukan dalam kurun waktu Maret 2013-Oktober 2014. Hasil penelitian menunjukkan prevalensi Salmonella spp. pada hasil perikanan segar adalah sebesar 32\% (45/141 sampel). Untuk uji resistensi antibiotik diketahui bahwa isolat Salmonella spp. resisten terhadap minimum 1 jenis antibiotik yaitu $31 \%$ resisten terhadap erythromycin, $11 \%$ terhadap amoxicillin clavulanic acid, $4 \%$ terhadap tetracycline, dan $2 \%$ terhadap doxycycline serta nalidixic acid. Satu isolat Salmonella spp. dari sampel kerang, diketahui resisten terhadap 4 jenis antibiotik (multidrug resistance) yaitu tetracycline, erythromycin, nalidixic acid,dan amoxicillin clavulanic acid. Sementara itu, 1 isolat Salmonella spp. resisten terhadap 3 jenis antibiotik (tetracycline, erythromycin dan amoxicillin clavulanic acid) dan 2 isolat resisten terhadap 2 antibiotik (erythromycin dan amoxicillin clavulanic acid). Prevalensi dan multi resistensi Salmonella spp. pada produk perikanan segar ini menunjukkan bahwa peluang kontaminasi bakteri tersebut pada bahan pangan yang umum dikonsumsi masyarakat cukup besar dan hal ini dapat menyebabkan gangguan kesehatan pada konsumen.
\end{abstract}

KATAKUNCI： Salmonella spp., multiresistensi antibiotik, produk perikanan segar, pasar domestik

\begin{abstract}
High incidences of Salmonella spp. in seafood have been reported worldwide in association with outbreaks of fever, nausea, vomiting and diarrhea. This study aimed to identify prevalence and antibiotic resistance of Salmonella isolated from fresh seafood samples, consisting of 110 samples of shrimp, 23 samples of fish, 4 samples of cephalopoda and 4 samples of shellfish. The samples were collected with purposive random sampling method from selected local market in DKI Jakarta and Bogor (West Java), Indonesia during March 2013 until October 2014. The prevalence of Salmonella was 32\% (45/141 samples) in fresh seafood products. The isolates were resistant to at least one antibiotic, $31 \%$ of erythromycin, $11 \%$ of amoxicillin clavulanic acid, $4 \%$ of tetracycline, and $2 \%$ of nalidixic acid. One isolate from bivalvia sample possessed multidrug resistance from four antibiotic agents (tetracycline, erythromycin, nalidixic acid and amoxicillin clavulanic acid). One isolate was resistant to 3 antibiotic agents (tetracycline, erythromycin and amoxicillin clavulanic acid) and two isolates were resistant to 2 antibiotic agents (erythromycin and amoxicillin clavulanic acid). The result showed that the fresh seafood samples from local market in Jakarta and Bogor were contaminated with potentially pathogenic Salmonella and could threat a public health.
\end{abstract}

KEYWORDS: Salmonella spp., multidrug resistance, fresh seafood products, domestic market 


\section{PENDAHULUAN}

Jaminan mutu dan keamanan pangan merupakan hal yang sangat penting dalam penyediaan bahan pangan, tidak saja untuk pasar ekspor tetapi juga pasar domestik, karena hal ini berimplikasi terhadap kesehatan konsumen. Penyediaan pangan dari sektor perikanan untuk memenuhi konsumsi domestik pada tahun 2014 adalah sebesar13.072 juta ton per tahun dengan penyediaan ikan per kapita adalah $51,8 \mathrm{~kg}$ dan rata-rata konsumsi ikan/kapita sebesar $31,14 \mathrm{~kg}$ (Pusat Data, Statistik dan Informasi, 2015). Ikan termasuk komoditas unggulan untuk mensuplai ketersediaan pangan bagi penduduk Indonesia. Bahan pangan ini sangat mudah mengalami pembusukan ( high perishable product) dan kerusakan lainnya yang disebabkan oleh kontaminasi mikroba dan bahan kimia yang berasal dari habitat hidupnya maupun dari cara penanganan dan pengolahan yang kurang baik. Salah satu bentuk cemaran biologi adalah kontaminasi produk pangan oleh bakteri patogen seperti Salmonella spp. yang dapat menyebabkan gangguan kesehatan (food borne diseases) pada konsumennya.

Salmonella spp.adalah bakteri Gram negatif berbentuk batang yang tidak membentuk spora. Bakteri ini bersifat patogen yang berbahaya bagi manusia dan hewan. Habitat utamanya adalah saluran usus hewan (burung, reptil, hama tanaman) dan manusia. Salmonelosis merupakan penyakit yang disebabkan oleh kontaminasi Salmonella melalui produk pangan dan menjadi permasalahan di dunia. Kasus salmonelosis yang menyebabkan penyakit diketahui berkisar $95 \%$ yang penyebarannya melalui pangan seperti daging, karkas ayam, telur, susu, produk perikanan dan bahan pangan segar lainnya. Salmonelosis dapat mengakibatkan gangguan kesehatan seperti gastroenteritis, bakterisemia, demam, kram perut, mual, muntah, dan pusing (Coburn, Grassl, \& Finlay, 2007; Foley \& Lynne, 2008; Jones et al., 2008; Newell et al., 2010). Sumber Salmonella pada bahan pangan sebagian besar berasal dari hewan termasuk produk perikanan. Penanganan yang tidak saniter dan higiene serta kurang sempurnanya proses pengolahan bahan pangan atau kontaminasi dari lingkungan merupakan faktor penyebab terjadinya infeksi Salmonella pada manusia (Lynch, Painter, Woodruff, \& Braden, 2006; Majowicz et al., 2010).

Informasi tentang prevalensi Salmonella spp. pada produk perikanan, telah beberapa kali dilaporkan, akan tetapi masih terbatas. Rusyanto (2005) menyampaikan bahwa prevalensi Salmonella spp. pada udang tambak di wilayah Tangerang adalah sebesar $26 \%$. Disamping itu teridentifikasi juga di rantai pengumpul di wilayah Karawang sebesar $70 \%$. Informasi lain juga menyebutkan bahwa sebanyak
$36 \%(9 / 25)$ produk udang putih (Penaeus merguiensis) segar yang terdapat di pasar tradisional di Surabaya diketahui tercemar Salmonella spp. (Narumi, Zuhriansyah, \& Mustofa 2009). Prevalensi Salmonella pada ikan segar yang diperoleh dari pasar tradisional dan supermarket di wilayah Bogor diketahui sebesar $10,34 \%$ (3/29) sampel (Azis, 2009). Kusumaningrum, Suliantari dan Dewanti-Hariyadi (2012) melaporkan bahwa sebanyak 10,3\% (3/29) sampel produk perikanan yang diperoleh dari pasar tradisional dan supermarket di wilayah Bogor teridentifikasi positif Salmonella spp.dengan perincian sebanyak $12,5 \%$ (1/8) berasal dari pasar tradisional dan 9,5\% (2/21) berasal dari supermarket. Hasil penelitian Anjung (2016) menyebutkan bahwa Salmonella ditemukan positif pada udang vannamei yang dibudidayakan di tambak di Kecamatan Wonosobo, Kota Agung dan Padang Cermin di wilayah Lampung dengan persentase berturut-turut $100 \%$ dan $33,3 \%$.

Penanganan terhadap penyakit yang disebabkan bakteri patogen umumnya dilakukan dengan memberikan antibiotik kepada individu yang telah terinfeksi. Namun, selama 70 tahun era penggunaan antibiotik untuk pengobatan manusia terhadap penyakit infeksi, bakteri patogen telah membentuk daya tahan (resistensi) klinis yang signifikan terhadap beberapa jenis antibiotik (Levy, 1998). Beberapa tahun terakhir, kecenderungan multiresisten Salmonella terhadap antibiotik yang diisolasi dari bahan pangan semakin meningkat. Hal ini diduga akibat penggunaan antibiotik yang tidak tepat dan berulang yang menyebabkan pengobatan untuk infeksi Salmonella pada manusia dan hewan akan semakin sulit (Choi et al., 2005; Frank et al., 2007; Kare et al., 1999; Khan et al., 2009; Lassmann, Gustafson, Wood, \& Rosenblatt, 2007; Vo, Van Duijkeren, Gaastra, \& Fluit, 2010; Wang et al., 2006; Zahurul et al., 2003). Data WHO menyebutkan bahwa terjadi 17 juta kasus salmonelosis yaitu demam tifoid per tahunnya dan 600 ribu kasus di antaranya menyebabkan kematian. Prevalensi demam tifoid yang merupakan kasus salmonelosis di Indonesia mencapai 358-810 per 100.000 populasi pada tahun 2007 dengan rata-rata pertahunnya sebesar 500 per 100.000 populasi (Hatta \& Ratnawati, 2008). Informasi mengenai tingkat resistensi Salmonella terhadap antibiotik menjadi sangat penting dalam rangka penanggulangan penyakit yang efektif dan efisien dan penentuan kebijakan tentang penggunaan antibiotik (Monica, Mahatmi \& Besung, 2013).

Penelitian ini memberikan informasi tentang prevalensi Salmonella hasil isolasi dari produk perikanan segar yang berasal dari pasar tradisional dan modern di wilayah DKI Jakarta dan Bogor serta profil resistensi bakteri ini terhadap antibiotik. 


\section{BAHAN DAN METODE}

Sampel yang dianalisis merupakan produk hasil perikanan dalam bentuk segar yang diperoleh dari pasar tradisional dan modern yang berlokasi di 5 wilayah Kotamadya DKI Jakarta dan Bogor, Jawa Barat. Pengambilan sampel dilakukan pada rentang waktu bulan Maret 2013-Oktober 2014 dengan jumlah sampel sebanyak 141 sampel yang berasal dari pasar tradisional sebanyak 121 sampel dan 20 sampel dari pasar modern.

Sampel yang diperoleh terdiri dari sampel udang (102 dari pasar tradisonal dan 8 dari pasar modern), sampel ikan ( 14 dari pasar tradisional dan 9 dari pasar modern), sampel cumi-cumi (3 dari pasar tradisional dan 1 dari pasar modern), dan sampel kerang (2 dari pasar tradisional dan 2 dari pasar modern). Sampel diambil secara aseptis kemudian dimasukkan ke dalam plastik steril dan disimpan dalam cool box yang suhunya dipertahankan $4{ }^{\circ} \mathrm{C}$ dengan penambahan es untuk selanjutnya dilakukan isolasi dan identifikasi Salmonella.

Isolasi dan identifikasi Salmonella spp. dilakukan berdasarkan ISO 6579:2002 dengan modifikasi yang mengacu pada Banerjee, ChenOoi, Shariff dan Khatoon (2012). Sampel sebanyak $25 \mathrm{~g}$ ditimbang dan ditambahkan ke dalam $225 \mathrm{ml}$ media pra pengayaan Buffered Peptone Water (BPW, Oxoid, England) dan diinkubasikan pada suhu $37^{\circ} \mathrm{C} \pm 1^{\circ} \mathrm{C}$ selama 24 jam. Homogenat dari media BPW diinokulasikan sebanyak $0,1 \mathrm{ml}$ ke dalam $10 \mathrm{ml}$ media Rappaport-Vassiliadis broth(RV, Oxoid, England) dan diinkubasikan ke dalam waterbath suhu $41,5 \pm 1^{\circ} \mathrm{C}$ selama $24 \pm 3$ jam. Tahap seleksi Salmonella dilakukan dengan memindahkan homogenat ke media agar selektif yaitu Xylose Lysine Deoxycholate (XLD, Oxoid, England) dan Brilliance Salmonella Agar (BSA, Oxoid, England) lalu diinkubasikan pada suhu $37 \pm 1^{\circ} \mathrm{C}$ selama $24 \pm 3$ jam. Konfirmasi Salmonella berdasarkan sifat biokimiawi dilakukan dengan menggunakan API 20E biochemical test kit (Biomerieux, France) dan uji serologi menggunakan antisera polivalen flagelar $(\mathrm{H})$ dan antisera polivalen somatik (O) (Remel, England).

Penentuan resistensi antibiotik Salmonella dilakukan dengan metode difusi cakram yang mengacu pada Clinical Laboratory Standard Institute (CLSI, 2012). Pengujian menggunakan 10 jenis antibiotik (Oxoid, England) yang terdiri dari amoxicillinclavulanic acid (Amc) $25 \mu \mathrm{g}$, ciprofloxacin (Cip) $5 \mu \mathrm{g}$, gentamycin (Gen) $10 \mu \mathrm{g}$, tetracycline (Tet) $30 \mu \mathrm{g}$,

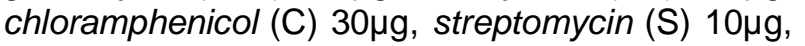
doxycycline (Do) $30 \mu \mathrm{g}$, nalidixic-acid (Na) $30 \mu \mathrm{g}$,

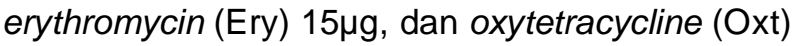
$30 \mu \mathrm{g}$. Kultur Salmonella hasil identifikasi ditumbuhkan di dalam media tryptic soy agar (TSA, Oxoid, England) pada suhu $37^{\circ} \mathrm{C}$ selama $18-24$ jam dan selanjutnya sebanyak 2-4 koloni disuspensikan ke dalam larutan garam fisiologis $0,85 \%$ sampai tercapai tingkat kekeruhan setara dengan standar 0,5 McFarland. Sebanyak 100-150 $\mu \mathrm{l}$ suspensi kultur dimasukkan ke dalam media Mueller Hinton Agar (Oxoid, England) lalu dituangkan ke dalam cawan petri steril dan didiamkan selama 15-30 menit sampai agar membeku. Kertas cakram yang mengandung antibiotik dengan dengan dosis tertentu ditempatkan di atas permukaan agar dan diinkubasi pada suhu 37 ${ }^{\circ} \mathrm{C}$ selama 18-24 jam. Pengamatan dilakukan dengan cara mengukur diameter zona hambat (zona bening) dan dibandingkan dengan standar penghambatan antibiotik berdasarkan Performance Standards for Antimicrobial Disk Susceptibility Tests yang ditetapkan oleh Clinical Laboratory Standard Institute (CLSI) untuk mengetahui tingkat resistensinya (CLSI, 2012).

\section{HASIL DAN BAHASAN}

Prevalensi Salmonella spp.pada produk perikanan segar yang diperoleh dari pasar tradisional dan modern di wilayah DKI Jakarta dan Bogor diketahui sebesar 32\% (45/141) sampel. Prevalensi Salmonella spp. tertinggi berturut-turut ditemukan pada produk kerang, udang segar, ikan, dan cumi-cumi (Tabel 1). Identifikasi Salmonella spp. diawali dengan tahap isolasi dan seleksi isolat Salmonella pada sampel dengan menggunakan media agar selektif.Hasil isolasi menunjukkan sebanyak 82/141 (58\%) sampel merupakan isolat tipikal Salmonella spp. berdasarkan hasil pengamatan pada media agar selektif BSA dan XLD. Selanjutnya berdasarkan hasil konfirmasi menggunakan API2OE biochemical test kit dan uji serologi, diketahui sebanyak 45 sampel teridentifikasi positif Salmonella spp.

Frekuensi ditemukan isolat Salmonella spp. tertinggi terdapat pada produk kerang segar yang diperoleh dari pasar tradisional dan modern yaitu sebesar $100 \%$. Tingginya keberadaan bakteri ini di bahan pangan tersebut, kemungkinan karena kerang dikenal sebagai hewan penyaring (filter feeder) dan pada umumnya diperoleh di perairan dekat muara sungai atau payau. Hal ini sejalan dengan laporan hasil penelitian Huss dan Gram (2004) bahwa kehadiran bakteri patogen termasuk Salmonella spp. banyak ditemukan pada jenis kekerangan. Kumar, Sharma, Sehgal dan Kumar (2008) melaporkan bahwa insiden Salmonella pada produk perikanan tergantung pada jenis produk perikanan tersebut. Kontaminasi ini kemungkinan disebabkan oleh lingkungan perairan yang tercemar bakteri atau akibat praktek penanganan dan tempat pendaratan produk tersebut yang jauh dari saniter dan higiene. Peningkatan keberadaan 
Tabel 1. Prevalensi Salmonella spp. pada produk perikanan segar yang berasal dari pasar tradisional dan modern di DKI Jakarta dan Bogor

Table 1. Prevalence of Salmonella spp. isolated from fresh seafood products from traditional and modern market in DKI Jakarta and Bogor

\begin{tabular}{lcccc}
\hline \multirow{2}{*}{$\begin{array}{c}\text { Jenis produk/ } \\
\text { Product type }\end{array}$} & $\begin{array}{c}\text { Jumlah sampel/ } \\
\text { No. of sample }\end{array}$ & \multicolumn{3}{c}{ Jumlah sampel positif/No. of positive sample (\%) } \\
\cline { 3 - 5 } & & $\begin{array}{c}\text { Tradisional/ } \\
\text { Traditional }\end{array}$ & $\begin{array}{c}\text { Modern/ } \\
\text { Modern }\end{array}$ & $\begin{array}{c}\text { Total/ } \\
\text { Total }\end{array}$ \\
\hline Udang/Shrimp & 110 & $30.4(31 / 102)$ & $25(2 / 8)$ & $30(33 / 110)$ \\
Ikan/Fish & 23 & $35.7(5 / 14)$ & $22.2(2 / 9)$ & $30(7 / 23)$ \\
Kerang/Bivalvia & 4 & $100(3 / 3)$ & $100(1 / 1)$ & $100(4 / 4)$ \\
Cumi-cumi/Chepalopoda & 4 & $0(0 / 2)$ & $50(1 / 2)$ & $25(1 / 4)$ \\
\hline \multicolumn{1}{c}{ Total } & 141 & $32.2(39 / 121)$ & $30(6 / 20)$ & \\
\hline
\end{tabular}

Salmonella spp. pada produk perikanan diduga karena kondisi air dan sistim budidaya, dimana akumulasi dari lingkungan yang tercemar menyebabkan peningkatan prevalensi Salmonella pada produk perikanan (Reilly \& Twiddy, 1992; Saheki, Kobayashi, \& Kawanishi, 1989).

Jika dibedakan berdasarkan tipe pasar, prevalensi lebih banyak ditemukan pada sampel dari pasar tradisional dibandingkan pasar modern. Selain dari segi jumlah sampel yang diperoleh juga lebih banyak, frekuensi ditemukan isolat Salmonella spp. dari sampel pasar tradisional adalah sebesar 32.2\% (39/ 121) sampel, lebih tinggi dibandingkan pada sampel di pasar modern, sebesar 30\% (6/20) sampel. Prevalensi Salmonella spp. yang dihasilkan dari penelitian ini cukup tinggi yaitu sebesar $32 \%$. Keberadaan Salmonella pada produk perikanan juga pernah disampaikan oleh Rusyanto (2005), yaitu sebanyak $26 \%$ Salmonella ditemukan pada udang tambak di wilayah Tangerang, 70\% Salmonella teridentifikasi pada udang tambak di rantai pengumpul yang berasal dari Karawang. Slamet (2000) menunjukkan udang segar dari Tanjung Kait dan Gebang telah terkontaminasi oleh Salmonella spp. dan diduga mikroorganisme tersebut adalah $S$. paratyphi A. Informasi lain juga menyebutkan bahwa sebanyak 36\% (9/25) produk udang putih (Penaeus merguiensis) segar yang terdapat di pasar tradisional di Surabaya diketahui tercemar Salmonella spp. (Narumi, Zuhriansyah, \& Mustofa, 2009). Kusumaningrum, Suliantri, dan Dewanti (2012) melaporkan bahwa sebanyak 10,3\% (3/29) sampel produk perikanan yang diperoleh dari pasar tradisional dan supermarket di wilayah Bogor teridentifikasi positif Salmonella spp., dengan perincian sebanyak 12,5\% (1/8) berasal dari pasar tradisional dan 9,5\% (2/21) berasal dari supermarket.

Bakteri Salmonella juga ditemukan pada produk perikanan untuk pasar ekspor yang berdampak pada penolakan ekspor produk perikanan asal Indonesia. Hasil penelitian pada udang beku ekspor yang diamati di 3 tahapan rantai pasok pengolahan udang beku (tambak, penerimaan bahan baku, produk akhir) diketahui sebanyak 2,94\% ( $n=34), 6,42 \%(n=65)$, dan $4 \%(n=75)$ teridentifikasi Salmonella spp. (Yennie, et al., 2015). Sementara itu, prevalensi Salmonella spp. juga ditemukan pada loin tuna di sepanjang rantai pasok pengolahan tuna beku untuk pasar ekspor, masing-masing sebesar $35.3 \%(n=17)$ di pendaratan ikan, $42.9 \%(n=14)$ di pos pengumpul, $25 \%(n=12)$ di miniplant, dan masih-masing $41.7 \%(n=12)$ di penerimaan bahan baku dan proses pengolahan di unit pengolahahan ikan (Yennie et al., 2016).

Produk perikanan diketahui merupakan salah satu sumber pembawa bakteri patogen penyebab gangguan kesehatan pada manusia termasuk Salmonella spp. Kontaminasi Salmonella pada produk perikanan dapat terjadi mulai dari ikan ditangkap atau dipanen sampai pada ikan dijual di pasar. Banyak faktor yang dapat menyebabkan kontaminasi Salmonella, mulai dari lingkungan penangkapan atau budidaya, penanganan saat pascapanen, selama trasportasi, dan penanganan saat produk perikanan dijual di pasar baik tradisional maupun modern (Bhaftopadhyay, 2000; Kamat et al., 2002; Upadhyay et al., 2010). Hasil penelitian menyebutkan bahwa hasil perikanan dalam bentuk segar merupakan sumber salmonelosis, terutama hasil perikanan yang diperoleh dari lingkungan yang terpapar limbah feses manusia atau hewan (Mol, Cosansu, Alakavuk, \& Ozturan, 2010; Norhana, Poolec, Deethah, \& Dykesd, 2010). Keracunan pangan yang berasal dari hasil perikanan, sebagian besar akibat dari konsumsi ikan mentah atau yang tidak diproses secara sempurna, atau juga karena kontaminasi silang selama penanganan maupun proses pengolahan. Kasus keracunan pangan karena bakteri termasuk Salmonella spp. yang terkait dengan konsumsi ikan dilaporkan sebanyak 12\% 
(Aberoumand, 2010; Huss, Reilly \& Embarek, 2000). Laporan Food and Drug Admininistration (USFDA) menyebutkan bahwa Salmonella spp. merupakan bakteri yang paling umum mencemari produk hasil perikanan (Allshouse et al., 2004). Studi terdahulu menunjukkan bahwa keberadaan Salmonella spp. pada produk perikanan yang diimpor ke USA dari beberapa negara, paling tinggi ditemukan pada produk perikanan asal Asia Pasifik yang diikuti oleh negara Afrika, Timur Tengah, dan Asia Tenggara (Heinitz, Ruble, Wagner, \& Tatini, 2000). Salah satu Salmonella yang banyak ditemukan pada produk perikanan adalah Salmonella hadar, dimana bakteri ini umum ditemukan di sampel yang berasal dari negara di Asia Tenggara, Meksiko, India, dan Timur Tengah (FAO, 2010).

Distribusi Salmonella pada produk perikanan, kemungkinan disebabkan adanya kontaminasi yang berasal dari pekerja yang menangani produk tersebut. Bagi negara-negara berkembang, kejadian salmonelosis dan prevalensi Salmonella pada produk pangan meningkat cukup signifikan (Saha et al., 2001). Byrd et al. (2002) melaporkan, rantai transportasi dan proses pengolahan pangan mungkin merupakan faktor penyebab utama kontaminasi silang pada tahapan tersebut. Pada umumnya Salmonella spp. banyak diisolasi dari lingkungan seperti tanah, muara sungai yang terkontaminasi oleh limbah dari manusia ataupun hewan. Selain itu, kontaminasi karena praktek penanganan yang salah selama transportasi produk pangan dan penggunaan es dan air yang tidak memenuhi persyaratan serta kontaminasi silang antar bahan pangan juga merupakan faktor utama tingginya prevalensi Salmonella spp. (Badonia, Ramachandran, \& Sankar 1988; Hatha \& Lakshmanaperumalsamy, 1997; Indrajith et al., 2015). Berdasarkan hasil pengamatan selama dilakukan pengambilan sampel baik di pasar tradisional maupun modern, kondisi pasar tradisional di hampir setiap wilayah di Indonesia memiliki kesamaan. Salah satu yang paling menonjol adalah masih belum memenuhi persyaratan sanitasi dan higiene. Di samping itu, ketersediaan air bersih dan es untuk mempertahankan rantai dingin produk masih minim. Potensi kontaminasi dari lingkungan, peralatan, penjual, dan kontaminasi silang cukup besar di pasar tradisional. Di pasar modern, seperti supermarket, yang penataan produknya telah dilengkapi dengan fasilitas yang memenuhi syarat sanitasi dan higiene, kemungkinan kontaminasi dapat disebabkan selama transportasi produk atau kontaminasi silang saat produk dipasarkan.

Hasil uji resistensi antibiotik dari isolat Salmonella spp. memiliki profil yang bervariasi. Pada penelitian ini diketahui bahwa isolat Salmonella spp. yang terdapat pada produk perikanan segar berturut-turut resisten terhadap minimum 1 antibiotik, yaitu $31 \%$ (14/45) terhadap erythromycin, $11 \%$ (5/45) terhadap amoxicillin clavulanic acid, 4\% (2/45) terhadap tetracycline, dan sebanyak $2 \%$ (1/45) masing-masing terhadap doxycycline dan nalidixic acid. Resistensi tertinggi Salmonella spp. dilaporkan terhadap erythromycin, yang ditemukan pada produk perikanan yang dijual di pasar tradisional maupun modern (Tabel 2).

Tabel 2. Pola resistensi antibiotik isolat Salmonella spp. asal produk perikanan segar dari pasar tradisional dan modern di DKI Jakarta dan Bogor

Table 2. Antimicrobial resistance pattern of Salmonella spp. isolated from fresh seafood products from traditional and modern market, in DKI Jakarta and Bogor

\begin{tabular}{clccc}
\hline \multirow{2}{*}{$\begin{array}{c}\text { Golongan antibiotik/ } \\
\text { Class of antibiotics }\end{array}$} & \multicolumn{1}{c}{$\begin{array}{c}\text { Jenis antibiotik/ } \\
\text { Antibiotics }\end{array}$} & \multicolumn{2}{c}{$\begin{array}{c}\text { Jumlah isolat Salmonella spp./ } \\
\text { No. of Salmonella spp. isolate(\%) }\end{array}$} \\
\cline { 3 - 5 } & & $\begin{array}{c}\text { Sensitif/ } \\
\text { Sensitive }\end{array}$ & $\begin{array}{c}\text { Intermediet/ } \\
\text { Intermediate }\end{array}$ & $\begin{array}{c}\text { Resisten/ } \\
\text { Resistance }\end{array}$ \\
\hline \multirow{2}{*}{ Kuinolon/Quinolonen } & Ciprofloxacin & $100(45 / 45)$ & 0 & 0 \\
& Nalidixic-acid & $96(43 / 45)$ & 0 & $4(2 / 45)$ \\
\hline Aminoglikosida/ & Gentamycin & $96(43 / 45)$ & $4(2 / 45)$ & 0 \\
Aminoglycoside & Streptomycin & $49(22 / 45)$ & $51(23 / 45)$ & 0 \\
\hline Tetrasiklin/ & Tetracycline & $96(43 / 45)$ & 0 & $4(2 / 45)$ \\
Tetracycline & Doxycycline & $96(43 / 45)$ & 0 & $4(2 / 45)$ \\
& Oxytetracycline & $100(45 / 45)$ & 0 & 0 \\
\hline Makrolida/ & \multirow{2}{*}{ Erythromycin } & $69(31 / 45)$ & 0 & $31(14 / 45)$ \\
\hline Lain-lain/Others & Chloramphenicol & $100(45 / 45)$ & 0 & 0 \\
& Amoxicillin clavulanic acid & $89(40 / 45)$ & 0 & $11(5 / 45)$ \\
\hline
\end{tabular}


Berdasarkan Tabel 2 Salmonella spp. dapat dihambat pertumbuhannya dengan penggunaan antibiotik jenis ciprofloxacin, chloramphenicol dan oxytetracycline, dimana Salmonella spp. menunjukkan senstivitas yang tinggi (100\%) pada ketiga jenis antibiotik tersebut. Antibiotik jenis gentamycin, tetracycline, doxycycline, dan nalidixic acid juga diketahui dapat menghambat pertumbuhan Salmonella spp. yang diperoleh di atas $95 \%$. Namun demikian beberapa isolat Salmonella spp. juga menunjukkan tingkat resistensinya pada antibiotik jenis tetracycline, doxycycline, dan nalidixicacid yaitu sebesar $4 \%$. Hal ini kemungkinan karena adanya variasi serovar Salmonella yang ditemukan pada sampel, mengingat pada penelitian ini, identifikasi Salmonella yang dilakukan hanya sampai tingkat genus dan tidak sampai ke serovarnya. Pada antibiotik streptomycin dan gentamycin, terlihat bahwa isolat Salmonella spp. bersifat intermediet sebesar $51 \%$ dan $4 \%$.

Sementara itu, diketahui ada isolat Salmonella spp. yang terdeteksi tersebut yang memiliki resistensi terhadap lebih dari 1 jenis antibiotik (multidrug resistance). Data penelitian menunjukkan bahwa terdeteksi 2 isolat yang resisten terhadap 2 jenis antibiotik (erythromycin, amoxicillin clavulanic acid), dari hasil isolasi udang segar yang berasal dari pasar modern. Sebanyak 1 isolat hasil isolasi dari ikan tenggiri yang dijual di pasar modern memiliki resistensi terhadap 3 jenis antibiotik (tetracycline, erythromycin, amoxicillin clavulanic acid) dan 1 isolat Salmonella spp. hasil isolasi dari sampel kerang yang berasal dari pasar modern juga resisten terhadap 4 jenis antibiotik (tetracycline, erythromycin, nalidixic acid, amoxicillin clavulanic acid). Profil multiresistensi isolat Salmonella spp. terhadap antibiotik ini disajikan pada Tabel 3.

Meningkatnya resistensi antibiotik pada bakteri Salmonella spp. telah dilaporkan di beberapa negara berkembang dan resistensi dari beberapa jenis antibiotik memicu munculnya multiresisten antibiotik (multidrug resistence) pada bakteri Salmonella (Ashtiani, Monajemzadeh, \& Kashi, 2009; White et al., 2001).Pada penelitian ini dilaporkan bahwa isolat Salmonella spp. memiliki resistensi tertinggi pada erythromycin yang merupakan golongan makrolida. Antibiotik ini merupakan golongan antibiotik yang telah lama digunakan sebagai pengobatan, terutama untuk bakteri patogen Gram negatif. Hal ini diduga karena adanya kontribusi sifat permukaan sel bakteri yang hidrofobik dan aktivitas pompa efflux pada bakteri yang dapat mengeluarkan antibiotik dari dalam sel sehingga konsentrasi antibiotik di dalam sel menjadi rendah sehingga tidak bekerja optimal (Braoudaki\& Hilton, 2005). Di Indonesia, antibiotik ini juga sering digunakan untuk pengobatan akibat infeksi Campylobacter (Tjaniadi et al., 2003). Beberapa hasil penelitian melaporkan tentang meningkatnya resistensi Salmonella spp. terhadap antibiotik ini, bahkan sampai $100 \%$ tingkat resistensinya (Akond et al., 2012; Cardoso et al., 2006; Ekwenye \& Kazi, 2007; Harakeh et al., 2005; Khan et al., 2005; Maripandi \& Al-Salamah, 2010; Singh, Agarwal,Tiwari

Tabel 3. Multiresisten antibiotik isolat Salmonella spp. asal produk perikanan segar dari pasar tradisional dan modern di DKI Jakarta dan Bogor.

Table 3. Multidrug resistance of Salmonella spp. isolated from fresh seafood products from traditional and modern market in DKI Jakarta and Bogor

\begin{tabular}{cccc}
\hline $\begin{array}{c}\text { Kode isolat/ } \\
\text { Isoate ID }\end{array}$ & $\begin{array}{c}\text { Resistensi/ } \\
\text { Resistance }^{\text {a }}\end{array}$ & $\begin{array}{c}\text { Jenis produk/ } \\
\text { Kind of product }\end{array}$ & $\begin{array}{c}\text { Asal produk/ } \\
\text { Product origin }\end{array}$ \\
\hline MHUK & Ery dan Amc & Udang/Shrimp & $\begin{array}{c}\text { Pasar modern/ } \\
\text { Modern market }\end{array}$ \\
MGUK & Ery dan Amc & Udang/Shrimp & $\begin{array}{c}\text { Pasar modern/ } \\
\text { Modern market }\end{array}$ \\
MYTI & Ery, Amc, dan Tet & Ikan tenggiri/ & Pasar modern/ \\
& Spanish mackerel & Modern market \\
MCKR & Ery, Amc, Tet, dan Na & Kerang/Bivalvia & Pasar modern/ \\
& & Modern market \\
\hline
\end{tabular}

a amoxicillin clavulanic acid (Amc), ciprofloxacin (Cip), gentamycin (Gen), tetracycline (Tet), chloramphenicol (C), streptomycin (S), doxycycline (Do), nalidixic acid (Na), erythromycin (Ery), dan oxytetracycline (Oxt) 
\& Singh, 2012). Kusumaningrum et al. (2012) juga melaporkan bahwa resistensi Salmonella terhadap erythromycin sebesar 75\% (15/20) pada produk segar seperti daging ayam, daging sapi, daging giling, ikan, sayur, yang berasal dari pasar tradisional dan supermarket di wilayah Bogor.

Antibiotik golongan kuinolon seperti nalidixic acid dan ciprofloxacin, merupakan antibiotik yang memiliki spektrum luas untuk pengobatan penyakit termasuk salmonelosis, terutama untuk pasien lanjut usia atau pasien dengan imunitas rendah. Hasil penelitian ini menunjukkan bahwa Salmonella masih cukup sensitif terhadap antibiotik golongan kuinolon ini, dengan tingkat sensitivitas $100 \%$ untuk ciprofloxacin dan $96 \%$ untuk nalidixic acid. Elhadi (2014) dan Singh, Agarwal, Tiwari, dan Singh (2012) juga melaporkan tingkat sensitivitas Salmonella terhadap ciprofloxacin adalah $92 \%$ dan $100 \%$, sedangkan nalidixic acid sebesar $67 \%$ dan $65 \%$. Namun demikian, resistensi Salmonella yang cukup tinggi (90-96\%) terhadap antibiotik jenis kuinolon terutama nalidixic acid juga pernah dilaporkan seperti di India, Banglades, dan Perancis (Cailhol et al., 2005; Chiou et al., 2014; Lakshmi, Ashok, Susmita, \& Shailaja, 2006). Resistensi Salmonella pada jenis kuinolon umumnya berhubungan dengan adanya mutasi pada Quinolone Resistant Determinant Region (QRDR) dari gen gyrA yang mengkode sub unit A dari DNA gyrase (Threlfall, Clifton-Hadley, Ridley, \& Davies, 2002).

Peningkatan resistensi bakteri Salmonella spp. terhadap antibiotik semakin banyak dilaporkan. Kondisi ini dipercepat karena semakin meningkatnya penggunaan antimikroba yang tidak rasional dan tidak tepat. Dalam jangka waktu 5 tahun setelah antibiotik baru digunakan untuk pengobatan, maka akan muncul resistensi antibiotik jenis tersebut dan hal ini juga memicu meningkatnya multiresistensi bakteri patogen termasuk Salmonella terhadap antibiotik. Semakin menurunnya pengembangan antibiotik baru dan belum adanya sistim pengendalian penggunaan antibiotik secara global, diperkirakan pada tahun 2050, resistensi mikroba akan menjadi pembunuh tertinggi di dunia dengan angka kematian diperkirakan 10 juta jiwa/tahun, dimana salah satu bakteri yang meningkat resistensinya terhadap antibiotik adalah Salmonella spp. Resistensi terhadap antibiotik meningkat disebabkan karena pola penggunaan antibiotik yang irasional dan tidak tepat pada manusia untuk tujuan pengobatan, namun demikian adanya faktor yang berasal dari pangan asal hewan seperti ikan, unggas, dan daging sapi memiliki kontribusi terbesar (80\%).

Munculnya multiresisten antibiotik oleh Salmonella terutama hasil isolasi dari bahan pangan termasuk perikanan, semakin meningkat terutama dari segi jenis antibiotiknya. Hasil penelitian ini menyebutkan bahwa terdapat isolat yang memiliki sifat multiresisten terhadap 2, 3 dan 4 jenis antibiotik. Beberapa hasil penelitian juga menyebutkan terjadinya multiresisten antibiotik Salmonella spp. pada produk perikanan. Chiou et al. (2014) menyatakan bahwa 2 isolat Salmonella typhi yang berasal dari sampel klinis memiliki multiresisten terhadap 4 dan 8 jenis antibiotik, yang merupakan hasil isolasi dari pasien asal Indonesia yang bekerja di Taiwan. Kasus demam tifoid yang terjadi di Taiwan periode tahun 2000-2013 sebanyak 19/80 kasus/tahun, dimana sebagian besar kasus salmonelosis ini berasal dari pekerja Indonesia di Taiwan (Wu, Chen, Lin, \& Yang, 2011). Sementara itu, pada sampel ikan yang berasal dari pasar tradisional di wilayah Bogor disebutkan terdapat isolat Salmonellayang multirensisten terhadap streptomycin dan erythromycin (Kusumaningrum et al., 2012).Multiresisten Salmonella juga ditemukan terhadap 3-4 jenis antibiotik pada sampel udang yang dijual di beberapa pasar di India (Hossain et al., 2012).

Multiresisten Salmonella yang dihasilkan pada penelitian ini terjadi pada golongan macrolide, tetracycline, quinolone serta gabungan amoxicillin dan clavulanic acid. Tetracycline merupakan jenis antibiotik generasi pertama yang banyak digunakan sebagai pengobatan karena harga dan ketersediaannya. Keadaan ini banyak ditemukan di negara-negara berkembang seperti Indonesia, India, dan negara asia lainnya (Wannaprasat, Padungtod, \& Chuanchuen, 2011). Pola multiresisten antibiotik juga ditemukan pada isolat Salmonella yang berasal dari sampel kekerangan hasil tangkapan di Perairan Maroko, dimana salah satu antibiotik yang tidak mampu menghambat Salmonella adalah dari golongan quinolone (nalidixic acid) (Boutaib, et al., 2015). Chloramphenicol, ampicilin, tetracycline merupakan jenis antibiotik generasi pertama yang digunakan untuk pengobatan infeksi Salmonella pada manusia (Hatta \& Ratnawati, 2008; Tjaniadi et al., 2003). Umumnya jika terjadi resistensi antibiotik generasi pertama, menurut pedoman pengendalian penyakit demam tifoid tahun 2006, pengobatan dilakukan dengan menggunakan jenis antibiotik generasi kedua seperti cefriaxone, cefixime, atau golongan quinolone (Kementerian Kesehatan, 2006). Di Indonesia dilaporkan bahwa kasus salmonelosis yang semakin meningkat adalah demam tifoid dan hal ini diikuti dengan meningkatnya resistensi bakteri ini terhadap beberapa jenis antibiotik (multiresisten) sejak tahun 2001 (Hatta \& Ratnawati, 2008).

Berdasarkan hasil penelitian, bahwa isolat Salmonella spp. yang berasal dari produk perikanan segar memiliki persentase multiresisten antibiotik 
sebesar 8,9\% (4/45). Hal ini juga dilaporkan oleh Lugito dan Cucunawangsih (2017), bahwa multiresisten Salmonella hasil isolasi sampel klinis pasien rumah sakit adalah sebesar 4,3\%. Multiresisten Salmonella terhadap antibiotik yang diisolasi dari unggas, domba, ikan, udang, sayur, dan produk olahan daging dari retail di beberapa kota di Propinsi Henan, Cina dengan persentase cukup tinggi dilaporkan oleh Yu, Jiang, Zhou, Wu, dan Wu (2014), yaitu 53,2\% sebanyak 1-3 antibotik, $27.4 \%$ sebanyak 4-6 antibiotik, dan $12,9 \%$ sebanyak $7-9$ antibiotik.

Prevalensi resistensi Salmonella terhadap antibiotik sangat bervariasi, yang dipengaruhi dari serovar, jenis sampel, lingkungan asal sampel dan lainnya. Namun demikian kecenderungan terjadinya peningkatan resistensi Salmonella terhadap antibiotik harus menjadi perhatian khusus terutama yang berasal dari pangan. Dibutuhkan upaya terpadu untuk mengatur pemakaian antibiotik sebagai obat secara tepat dan bertanggung jawab terutama di negaranegara berkembang, karena diketahui pasien yang berada di rumah sakit di atas 5 hari merupakan pembawa (carier) bakteri yang resisten terhadap antibiotik. Hal penting lainnya adalah penggunaan antibiotik secara tepat pada hewan sebagai bahan baku pangan perlu dilakukan guna membatasi risiko pengalihan patogen bawaan pangan kepada manusia (Zhao, Datta, Ayers, Friedman, Walker, \& White, 2003).

\section{KESIMPULAN}

Prevalensi Salmonella spp. pada produk perikanan segar yang diperoleh dari pasar tradisional dan modern di wilayah DKI Jakarta dan Bogor diketahui sebesar 32\% (45/141) sampel yang berturut-turut ditemukan pada produk kerang $(100 \%)$, udang segar (30\%), ikan (30\%), dan cumi-cumi (25\%). Prevalensi Salmonella spp. ini menunjukkan bahwa peluang kontaminasi bakteri tersebut pada bahan pangan yang umum dikonsumsi masyarakat cukup besar dan dapat menyebabkan gangguan kesehatan pada konsumen. Resistensi isolat Salmonella spp.terhadap minimum 1 jenis antibiotik adalah sebesar $31 \%$ resisten terhadap erythromycin, $11 \%$ terhadap amoxicillin clavulanic acid, $4 \%$ terhadap tetracycline, dan $2 \%$ terhadap doxycycline serta nalidixic acid. Satu isolat Salmonella spp. dari sampel kerang, diketahui resisten terhadap 4 jenis antibiotik (multidrugresistance) yaitu tetracycline, erythromycin, nalidixic acid dan amoxicillin clavulanic acid. Sementara itu, 1 isolat Salmonella spp. resisten terhadap 3 jenis antibiotik (tetracycline, erythromycin, amoxicillin clavulanic acid) dan 2 isolat resisten terhadap antibiotik (erythromycin, amoxicillin-clavulanic acid). Upaya terpadu dalam pengaturan antibiotik sebagai obat pada manusia secara tepat dan bertanggung jawab sangat dibutuhkan termasuk pengaturan penggunaan antibiotik pada hewan,sehingga peluang bakteri patogen yang resisten terhadap antibiotik tidak semakin besar.

\section{DAFTAR PUSTAKA}

Aberoumand, A. (2010). Estimation of microbiological variations in Minced Lean fish products. World J. Fish Mar. Sci., 2(3): 204-207.

Akond, M. A., Shirin, M., Alam, S., Hassan, S. M. R., Rahman, M. M., \& Hoq, H. (2012). Frequency of drug resistant Salmonellaspp. isolated from poultry samples in Bangladesh. $S J$ Microbiol., 2(1): 15-19.

Allshouse, J., Buzby J., Harvey, D.,\& Zorn, D. (2004).Seafood Safety and Trade.Agriculture Information Bulletin Number 789.USDA.

Anjung, M.U.K. (2016). Identifikasi cemaran Salmonella $\mathrm{sp}$ dan isolasi bakteriofage sebagai biokontrol dalam penanganan pasca panen udang vannamei (Litopennaus vannamei). Tesis. Fakultas pertanian, Universitas Lampung.

Ashtiani, M.T., Monajemzadeh, M.,\& Kashi, L. (2009). Trends in antimicrobial resistance of fecal Shigella and Salmonella isolates in Tehran, Iran.Indian J. Path.Microbiol., 52, 52-55.

Azis, I. (2009). IsolasiSalmonellaspp.pada tiga jenis ikan di wilayah bogor serta uji ketahanannya terhadap pengaruh proses pengukusan. Skripsi. Fakultasteknologi pertanian, Institut Pertanian Bogor.

Badonia, B., Ramachandran, A., \& Sankar, T.V. (1988).Quality problems in fish processing.J. Indian Fish. Assoc. 18, 283-287.

Banerjee, S., ChenOoi, M., Shariff, M., \& Khatoon, H. (2012). Antibiotic Resistant Salmonella and Vibrio Associated with Farmed Litopenaeus vannamei. Scientific World Journal, (2012). https://doi:10.1100/ 2012/130136.

Bhaftopadhyay, P. (2000). Fish-catching and handling. In: Robinson, RK. (Ed.),. In: Encycl. Food Microbiol.vol. 2. Academic Press, London. p1547.

Boutaib, R., Bouchrif, B., Abid, M., Karraouan, B., Khaddor, M.,\& Laglaoui, A. (2015). Multidrug resistance of Salmonellaisolated from shellfish samples Morocco. Br Microbiol Res J. 8(6): 663-669.

Braoudaki, M.,\&Hilton, A.C. (2005). Mechanisms of resistance in Salmonellaenterica adapted to erythromycin, benzalkonium chloride and triclosan. Int. J. Antimicrob. Agents, 25, 31-37.

Byrd, J.A., Hargis, B.M., Corrier, D.E., Brewer, R.L., Caldwell, D.J., Bailey, R.H., McReynolds, J.L., Herron, K.L., \& Stanker, L.H. (2002). Fluorescent marker for the detection of crop and upper gastrointestinal leakage in poultry processing plants.Poult. Sci.,81,70-74.

Cailhol, J., Lailler, R., Bouvet, P., Vieille, S.L., Gauchard, F., Sanders, P., \& Brisabois, A. (2005). Trends in 
antimicrobial resistance phenotypes in non-typhoid Salmonella from human and poultry origins in France.Epidemiology and Infection. 134: 171-178.

Cardoso, M.O., Ribeiro, A.R., dos Santos, L.R., Pilotto, F., Moraes, H.L. S., Salle, C. T.P., Rocha, S.L., Silveira, \&Nascimento, V.P. (2006). Antibiotic resistance in Salmonellaenteritidis isolated from broiler carcasses. Braz. J. Microbiol.37: 368-371.

Chiou, C.S., Lauderdale, T.L.,Phung, D.C., Watanabe, H., Kuo, J.C., Wang, P.J., Liu, Y.Y., Liang, S.Y.,\&Chen, P.C. (2014). Antimicrobial resistance in Salmonellaentericaserovar typhi isolates from Bangladesh, Indonesia, Taiwan, and Vietnam. Antimicrob.Agents Chemother. 58(11): 6501-6507.

Choi, S-H., Woo, J.H., Lee, J.E., Park, S.J., Choo, E.J., Kwak, Y.G., Kim, M-N., Choi, M-S., Lee, N.Y., Lee, B.K., Kim, N.J., Jeong, J-Y., Ryu, J.,\& Kim, Y.S. (2005). Increasing incidence of quinolone resistance in human non-typhoid Salmonellaenterica isolates in Korea and mechanisms involved in quinolone resistance. J. Antimicrob. Chemother. 56, 1111-1114.

Clinical and Laboratory Standards Institute (CLSI).(2012). Performance standards for antimicrobial disk susceptibility tests: Approved standard. Wayne, Pennsylvania, 76.

Coburn, B., Grassl, G.A.,\& Finlay, B.B. (2007). Salmonella, the host and disease: a brief review. Immunol. Cell Biol., 85, 112-118.

Corwin, A. L., \& Oyofo, B. A. (2003).Antimicrobial resistance of bacterial pathogens assosiated with diarrheal patients in Indonesia.Am. J. Trop. Med. Hyg., 68, 666-670.

Ekwenye, U. N., \& Kazi, E. (2007). Investigation of plasmid DNA and antibiotic resistance in some pathogenic organisms.Afr. J. Biotechnol., 6, 877-880.

Elhadi, N. (2014). Prevalence and antimicrobial resistance of Salmonellaspp. in raw retail frozen imported freshwater fish to eastern province of Saud Arabia. Asian Pac. J. Trop. Biomed., 4 (3), 234-238.

Foley, S. L., \& Lynne, A. M. (2008). Food animalassociated Salmonella challenges: pathogenicity and antimicrobial resistance. J Anim Sci., 86, 173-187.

Food and Agricultural Organization. (2010). Expert Workshop on the application of biosecurity measures to control Salmonella contamýnatýon in sustainable aquaculture. FAO Fisheries and Aquaculture Report No. 937 ISSN 2070-6987, Mangalore, India, 19-21 January 2010.

Frank, M. A., Rene, S. H., Jana, L., Katie, G., Kathryn, T., Patrick, F.M., David, G.W., ....... \& Peter, G-S. (2007). International Spread of Multidrug-resistant Salmonellaschwarzengrund in Food Products. Emerg. Infect. Dis., 13(5), 726-731.

Harakeh, S., Yassine, H., Gharios, M., Barbour, E., Hajjar, S., El-fadel, M., Toufeili, I., \& Tannous, R. (2005). Isolation, molecular characterization and antimicrobial resistance patterns of Salmonella and Escherichia coli isolates from meat-based fast food in Lebanon.Sci. Total Environ., 341, 33-44.
Hatha, M. A. A.,\& Lakshmanaperumalsamy, P. (1997).Prevalence of Salmonella in shellfish and crustaceans from markets in Coimbatore, South India. Food Microbiol., 14, 111-116.

Hatta, M.,\& Ratnawati. (2008). Enteric fever in endemic areas of Indonesia: an increasing problem of resistance. J Infect Dev Ctries., 2, 279-282.

Heinitz, M. L., Ruble, R. D., Wagner, D.E., \& Tatini, S. R. (2000). Incidence of Salmonella in fish and seafood. J. Food Prot., 63, 579-592.

Hossain, M. S., Aktaruzzaman, M., Fakhruddin, A. N. M., Uddin, M. J., Rahman, S. H., Chowdhury, A. Z., \& Alam, M. K. (2012). Prevalence of multiple drug resistant pathogenic bacteria in cultured black tiger shrimp (Penaeus monodon Fabricius). Global J. Environ. Res., 6 (3), 118-124.

Huss, H. H., Reilly, A., \& Embarek, P. K. B. (2000).Prevention and control of hazards in seafood.Food Control. 11, 149-156.

Huss, H.H.,\& Gram, L. (2004).Assessment and management of seafood safety and quality. Food and Agriculture Organization ofThe United Nations, Rome: 1-53.

Jones,T. F., Ingram, L. A., Cieslak, P. R., Vugia, D. J., Tobin-D'Angelo, M., Hurd, S., Medus, C., Cronquist, A.,\& Angulo, F. J. (2008). Salmonellosis outcomes differ substantially by serotype. Int. J. Infect. Dis., 198,109-114.

Indrajith, S., Athmanathan, B., Subbaraj, D.K., Meganathan, V., Arockiaraj, J. E. E., Woodrowwilson, J.E.,\& Karuppannan, S. (2015). Incidence and antibiotic resistant profiles of pathogenic Salmonellaspp. from different environmental and food samples.Int. J. Microbiol. Immunol. Res.,3(6), 76-83.

International Organization for Standardization. (2002). ISO 6579:2002: Microbiology of food and animal feeding stuffs -Horizontal method for the detection of Salmonella spp.

Kamat, A. S., Bandekar, J. R. M., Karani, S., Jadhav, R., Shashidhar, A., Kakatkar, S., Pingulkar, K., ......\& Bhat, A., (2002). Microbiological quality of some major fishery products exported from India. In: International Atomic Energy Agency document. Proceedings of a Final Research Coordination Meeting on Determination of Human Pathogen Profiles in Food by Quality Assured Microbial Assays, Mexico City, Mexico, 22-26 July, 51-61.

Kare, M., Dortelaubaggesen, Frank, M. A., Jens, M. E., Jorgen, E., Kai, F., Peter, G-S., Andreas, M. P., \& Henrikc. (1999). An outbreak of multidrug-resistant, quinolone-resistant Salmonellaenterica serotype typhimurium. N. Engl. J. Med., 341, 1420-1425.

Kementerian Kesehatan. (2006). Panduan pengendalian deman tifoid. Peraturan MenKes no. 364/MENKES/ SK/ V/2006.

Khan, M. F. R., Rahman, M. B., Khan, M. S. R.,\& Nazir, M. N. H. (2005). Antibiogram and plasmid profile analysis of isolated poultry Salmonella of 
Bangladesh. Pakistan Journal of Biological Sciences. 8, 1614-1619.

Khan, A. A., Ponce, E., Nawaz, M. S., Cheng, C. M., Khan, J. A., \& West, C. S. (2009). Identification and characterization of class 1 integron resistance gene cassettes among Salmonella strains isolated from imported seafood. Appl. Environ. Microbiol., 75(4),1192-1196.

Kumar, Y., Sharma, A., Sehgal, R., \& Kumar, S. (2008). Distribution trends of Salmonella serovars in India (2001-2005). Trans. R. Soc. Trop. Med. Hyg., 103, 390394.

Kusumaningrum, H. D., Suliantari, \& Dewanti-Hariyadi, R. (2012). Multidrug resistance among different serotypes of Salmonella isolates from fresh products in Indonesia. Int Food Res J., 19(1), 57-63.

Lakshmi, V., Ashok, R., Susmita, J., \& Shailaja, V. V. (2006). Changing trends in the antibiograms of Salmonella isolates at a tertiary care hospital in Hyderabad. Indian Indian J Med Microbiol., 24, 4548.

Lassmann, B., Gustafson, D.R., Wood, C. M., \& Rosenblatt, J. E. (2007). Re-emergence of anaerobic bacteremias.Clin.Infect. Dis., 44,895-900.

Levy, S. B. (1998). The challenge of antibiotic resistance.Sci. Am., 46-53.

Lynch, M., Painter, J., Woodruff, R., \& Braden, C.,(2006). Surveillance for foodborne-disease outbreaksUnited States, 1998-2002. MMWR Surveill Summ., 55,1-42.

Lugito, N. P. H., \& Cucunawangsih. (2017). Antimicrobial Resistance of Salmonellaentericaserovars typhi and paratyphi isolates from a general hospital in Karawaci, Tangerang, Indonesia: A five-year review.Int J Microbiol.,(2017), 7.

Majowicz, S. E., Musto, J., Scallan, E., Angulo, F. J., Kirk, M., O'Brien, S.J., Jones, T.F., Fazil , A., \&Hoekstra, R.M. (2010). The global burden of nontyphoidal Salmonella gastroenteritis.Clin. Infect. Dis., 50(6), 882-889.

Maripandi, A.,\& Al-Salamah, A.A. (2010). Multiple-antibiotic resistance and plasmid profiles of Salmonellaenteritidis isolated from retail chicken meats. J Food Sci Technol., 5, 260-268.

Mol, S., Cosansu, S., Alakavuk, D.U.,\& Ozturan, S., (2010). Survival of Salmonellaenteritidis during salting and drying of horse mackerel (Trachurus trachurus) fillets.Int. J. Food Microbiol.,139, 36-40.

Monica, S.M., Mahatmi, H.,\& Besung,K. (2013). Pola resistensi Salmonella typhi yang diisolasi dari ikan serigala (Hoplias malabaricus) terhadap antibiotik. Jurnal IImu dan Kesehatan Hewan. 1(2), 64-69.

Narumi, H.E., Zuhriansyah,\& Mustofa, I.(2009). Deteksi pencemaran bakteri Salmonella sp. pada udang putih (Penaeus merguiensis) segar di pasar tradisional Kotamadya Surabaya. Jurnal IImiah Perikanan dan Kelautan. 1(1), 87-91.

Newell, D.G., Koopmans, M., Verhoef, L., Duizer, E., Aidara-Kane, A., Sprong, H., Opsteegh, M., Langelaar, M., Threfall, J., Scheutz, F., van der Giessen,
J.V.,\&Kruse, K.(2010). Food-borne diseases - the challenges of 20 years ago still persist while new ones continue to emerge. Int J Food Microbiol., 139 (suppl. 1), 3-15.

Norhana, M.N.W., Poolec, S.E., Deethah, C.,\& Dykesd, G.A. (2010). Prevalence, persistence and control of Salmonella and Listeria in shrimp and shrimp products.J. Food Control. 21(4), 343-361.

Pusat Data Statistik, dan Informasi-Kementerian Kelautan dan Perikanan. (2015). Perikanan dalam angka 2014. Kementerian Kelautan dan Perikanan.

Reilly, P. J.,\& Twiddy, D. R. (1992).Salmonella and Vibrio cholerae in brackishwater cultured tropical prawns. Int. J. Food Microbiol., 16(4), 293- 301.

Rusyanto, W. (2005). Prevalensi serovar dan galur resisten antibiotik Salmonellapada rantai produksi udang tambak.Tesis. Bogor: Sekolah Pascasarjana, Institut Pertanian Bogor.

Saha, S. K., Darmstadt, G. L., Baqui, A. H., Hanif, M., Ruhulamin, Santosham, M., Nagatake, T., \& Black, R. E. (2001). Rapid identification and antibiotic susceptibility testing of Salmonellaentericaserovar typhisolated from blood: Implications for therapy. $J$ Clin Microbiol. 39(10), 3583-3585.https://doi: 10.1128/JCM.39.10.3583-3585.2001.

Saheki, K., Kobayashi, S., \& Kawanishi, T. (1989). Salmonella contamination of eel culture ponds. Nippon Suisan Gakkashi. 55, 675-679.

Singh, S., Agarwal, R. K., Tiwari, S. C., \& Singh, H. (2012). Antibiotic resistance pattern among the Salmonella isolated from human, animal and meat in India. Trop Anim Health Prod., 44, 665-674.

Slamet. (2000). Cemaran mikrobiologis udang tambak segar di Jawa Barat. Skripsi. Fakultas Teknologi Pertanian, Institut Pertanian Bogor.

Threlfall, E. J., Clifton-Hadley, F. A., Ridley, A. M.,\& Davies, R. H. (2002).Comparison of gyrA mutations, cyclohexane cesistance, and the presence of class I Integrons in Salmonellaenterica from farm animals in England and Wales.J. Clin. Microbiol., 40, 14811486.

Tjaniadi, P., Lesmana, M., Subekti, D., Machpud, N., Komalarini, S., Santoso, W., Simanjuntak, C.,..... \& Rahmawati. (2008). Enteric fever in endemic areas of Indonesia: an increasing problem of resistance. $J$ Infect Dev Ctries, 2, 279- 282.

Upadhyay, B. P., Utrarachkij, F., Thongshoob, J., Mahakunkijcharoen, Y., Wongchinda, N., Suthienkul, O., \& Khusmith, S. (2010). Detection of SalmonellainvA gene in shrimp enrichment culture by polymerase chain reaction. Southeast Asian J Trop Med Public Health. 41(2), 426-435.

Vo, A.T., Van Duijkeren, E., Gaastra, W., \& Fluit, A. C. (2010). Antimicrobial resistance, class 1 integrons, and genomic island 1 in Salmonella isolates from Vietnam. PLoS One. 5(2): 9440.1-8.

Wang, H. H., Manuzon, M., Lehman, M., Wan, K., Luo, H., Wittum, T. E., Yousef, A., \& Bakaletz, L. O. (2006). Food commensal microbes as a potentially important avenue in transmitting antibiotic resistance 
genes.FEMS Microbiol.Lett., 254, 226-231. doi: 10.1111/j.1574-6968.2005.00030.x

Wannaprasat, W., Padungtod, P., \& Chuanchuen, R. (2011). Class 1 integrons and virulence genes in Salmonellaenterica isolates from pork and humans. Int. J. Antimicrob. Agents. 37,457-461.

White, D. G., Zhao, S., Sudler, R., Ayers, S., Friedman, S., Chen, S., McDermott, P. F., McDermott ,S., Wagner, D. D.,\& Meng, J. (2001). The isolation of antibioticresistant Salmonella from retail ground meat. $N$. Engl. J. Med.,345(16):1147-1154.

Wu, L. J., Chen, W. C., Lin, M. C., \& Yang, S.Y. (2011). The epidemic and interventions in imported typhoid among Indonesian labors in 2009. Taiwan Epidemiol. Bull.,27,67-74.

Yennie, Y., Kusmarwati, A., Hermana, I., Ariyani, F., Wibowo, S., \& Kusumaningrum, H. D. (2015). Kajian risiko mikrobiologi Salmonella pada produk udang beku. Laporan Teknis Peneltian dan Pengembangan TA. 2015. Balai Besar Penelitian dan Pengembangan Pengolahan Produk dan Bioteknologi Kelautan dan Perikanan-KKP.

Yennie, Y., Gunawan, Kusmarwati, A., Indriati, N., Wibowo, S., \& Kusumaningrum, H. D. (2016). Kajian risiko Salmonella pada tuna tangkapan nelayan kecil Ambon. Laporan Teknis Peneltian dan Pengembangan TA.2016. Pusat Penelitian dan Pengembangan Daya Saing Produk dan Bioteknologi Kelautan dan Perikanan, KKP.

Yu, T., Jiang, X., Zhou, Q., Wu, J., \& Wu, Z. (2014). Antimicrobial resistance, class 1 integrons, and horizontal transfer in Salmonella isolated from retail food in Henan, China. J Infect Dev Ctries., 8(6),705711.

Zhao, S., Datta, A. R., Ayers, S., Friedman, S., Walker, R. D.,\& White, D.G. (2003). Salmonella serovars isolated from imported foods. International Journal 
JPB Kelautan dan Perikanan Vol. 12 No. 1 Tahun 2017: 79-90 